\title{
MORPHOMETRIC ANALYSIS OF THE SUBMARINE ARC VOLCANO MONOWAI (TOFUA-KERMADEC ARC) TO DECIPHER TECTONOMAGMATIC INTERACTIONS
}

Wormald, Sarah C, Wright, Ian C., Bull, Jonathan M., Lamarche, Geoffroy and Sanderson, David J.(2012). Morphometric analysis of the submarine arc volcano Monowai (Tofua - Kermadec Arc) to decipher tectono-magmatic interactions. Journal of Volcanology and Geothermal Research, 239-240, 6982.

\section{(doi:10.1016/j.jvolgeores.2012.06.004).}

\section{Abstract}

Morphometric analysis of multibeam bathymetry and backscatter data is applied to Monowai, a submarine volcano of the active Tofua - Kermadec Arc to map and document the structure and evolution of the volcanic centre. Low rates of erosion and sedimentation, and pervasive tectonic and magmatic processes, allow quantification through detailed structural analysis and measurement of deformation. The Slope, Aspect, Curvature, Rugosity, and Hydrology (flow) tools of ArcGIS provide a robust structural interpretation and the development of a model of Monowai evolution.

A nested caldera structure with a volume of $\sim 31 \mathrm{~km}^{3}$ and a stratovolcano of $\sim 18 \mathrm{~km}^{3}$ dominate the magmatic constructs. The outer caldera is elongate along $125^{\circ}$, and the inner caldera along $135^{\circ}$. Numerous parasitic cones and fissure ridges are also observed, oriented at $039^{\circ}$ and $041^{\circ}$, respectively. Northeast trending faults (with a regional average strike of $031^{\circ}$ ) are widespread within this part of the backarc, forming a nascent rift graben to the west of the Monowai caldera complex. The distribution of throw varies spatially, reaching a maximum total along-rift of $320 \mathrm{~m}$ and across rift of $120 \mathrm{~m}$, with greater throw values measured in the west.

Elongation directions of the two nested calderas are near-perpendicular to the trends of faults and fissure ridges. The inner caldera is more orthogonal to the magmatic constructs (fissure ridges and aligned vent cones) and the outer caldera is approximately orthogonal to the regional fault fabric, suggesting a strong interaction between magmatic and tectonic processes, and the directions of the horizontal principal stress directions. We present a detailed morphometric analysis of these relationships and the data are used to interpret the spatial and temporal evolution of the tectono-magmatic system at Monowai, and classify the type of rifting as transtensional. Similar analysis is possible elsewhere in the Kermadec backarc and within other regions of submarine volcanism. 


\section{INTRODUCTION}

Magmatic processes and tectonic deformation are closely interrelated, and control seafloor morphology in many modern and active arc-backarc systems, such as at the Izu-Bonin-Mariana Arc (Taylor, 1992) and the South Sandwich Arc (Leat et al., 2010). Hence, morphometric analysis of active arc-backarc systems may provide insight into the relative role of tectonic deformation and magmatic activity in controlling the evolution and development of these volcanic systems. Subaerial volcano morphology can be analysed using a combination of remotely-sensed data such as high-resolution aerial photography (e.g., Pyle and Elliott, 2006; Hauber et al., 2010), LiDAR (e.g., Favalli et al., 2009), and SAR (Rowland et al., 1999), to which ground-truth data are relatively easily provided through fieldwork. Active deformation is also commonly recorded using InSAR (e.g., Calais et al., 2008; Keir et al., 2011). In contrast, study of submarine (or extraterrestrial) volcanoes presents a greater challenge as observations and sampling are inherently more difficult. Vessel-borne multibeam echo-sounder systems have the dual advantage of providing continuous coverage, and mapping of the seafloor at resolutions of $\sim 25 \mathrm{~m}$ horizontally and $1 \mathrm{~m}$ vertically (e.g. Wright et al., 2006a). Similarly, multibeam systems borne by Autonomous Underwater Vehicles (AUV) and other underwater vehicles can provide much improved horizontal and vertical resolutions, e.g., $2 \mathrm{~m}$ horizontal and $15 \mathrm{~cm}$ vertical resolutions at $4 \mathrm{~km}$ water depth (e.g., Huvenne et al., 2009). The use of backscatter data generated together with bathymetry by multibeam echosounder systems, provide a means to quantitatively characterise seafloor substrate and micro-topography (e.g., Brown and Blondel, 2009; Lamarche et al., 2011). Analysis of submarine volcanic systems using multibeam bathymetry and backscatter data, can fully document the interaction between tectonic and magmatic processes (e.g., Mitchell and Lofi, 2008).

Arc-backarc systems hosted within young oceanic arc crust, such as the TofuaKermadec Arc with low rates of erosion and sedimentation, provide an ideal location to study the interaction of magmatism and tectonism, as effects from inherited structures that do not result from the current tectonic setting are limited. For clarity we define: tectonism as the deformation of the crust through faulting, magmatism as 
the presence of deeper intrusives which do not break the surface of the crust, whereas volcanism is the surficial expression of magmatism. Magmatic structures may occur along a continuum from constructional vent cones and fissure ridges (both of which may be partly volcanic after eruption), to destructional (mainly volcanic) structures such as calderas. Boundaries between the process definitions can become unclear, such as where tectonic and magmatic processes interact, forming regions of tectonomagmatism (e.g., Francis and Oppenheimer, 2004). Tectono-magmatic interactions differ in form with the relative timing of the two processes, and the interaction of the regional stress field and basement crustal structures (Lara et al., 2006), as the tectonic force and surface heat flow control the depth of magma emplacement (Watanabe et al., 1999). Surficial structures indicating the interaction of these processes at depth range from caldera collapse, dyke injection inducing faulting (Rubin and Pollard, 1988), rifting episodes such as the 2005 Dabbahu (Afar) event (Wright et al., 2006b), fissure swarms (e.g. Sonnette et al., 2010) to volcanoes in rifts focusing extension (van Wyk de Vries and Merle, 1996).The Kermadec Arc - Havre Trough backarc system (Figure 1A) comprises active rifting west of constructional arc front volcanism. Between the backarc rifting and the arc front there is a varying dominance of parasitic cones, fissure ridges, and pervasive extensional faulting (e.g., Wright et al., 2006a; Campbell et al., 2007; Graham et al., 2008; Wysoczanski et al., 2010). Interactions of magmatism and tectonism can record the dominant mechanism driving the structural evolution of the arc-backarc system.

Studies of the interaction of magmatism and tectonism globally (e.g., Dauteuil and Bergerat, 2005; Cembrano and Lara, 2009; Sonnette et al., 2010 among others), and the associated modelling (e.g., Corti et al., 2003; Mathieu et al., 2011) provide a context for the analysis of the Kermadec Arc - Havre Trough backarc system. For example if volcanism occurs before tectonism, it can control later fault structures and rift formation, increasing and reorientating stresses, with faults curving towards the volcano where extension is focused (van Wyk de Vries and Merle, 1996). Volcanism may also affect nearby faults, by the transfer of stress or through magma chamber movement as postulated at the Okataina volcanic centre (New Zealand), where $30 \%$ of fault ruptures occurred during eruption (Villamor et al., 2011). Conversely, tectonic 
activity can also affect the eruptive products of a volcano in a fault system (van Wyk de Vries and Merle, 1996; Bellotti et al., 2006), or may lead to a hiatus of volcanic activity (Bellotti et al., 2006). The extent of tectonic control on volcanism has been determined clearly at the Cordón Caulle-Puyehue area of the Southern Andes (Lara et al., 2006), with local variations of the trends of fissure systems and monogenetic cones indicative of magmatic compositions. On a smaller scale, Corazzato and Tibaldi (2006) find parasitic pyroclastic cones to be influenced by a north-south rift system at Mt. Etna, Italy, which may control the alignment of "magma-feeding fractures". Spinks et al. (2005) interpret tectonism to control volcanism, with calderas close to the Taupo Volcanic Zone (New Zealand) axial rift consisting of multiple eruption collapse structures, compared to monogenetic calderas further from the rift, in addition to the amount of magma erupted possibly a function of the extension rate. While also within the Taupo Volcanic Zone rifting mechanisms appear to vary according to the magmatic style (Rowland et al., 2010), suggesting the dominant process (whether magmatism or tectonism) may be hard to identify definitively where the processes are coeval.

Coeval tectonism and magmatism can be more difficult to decipher as being driven by a particular process, if analysis is conducted after the interaction. Geophysical surveying aided the analysis of the coeval events within the tectono-magmatic history of Thingvallavatn, an Icelandic lake where a single dyking event drove normal faulting and producing an asymmetric rift (Bull et al., 2005). The high magmatic input of the underlying hot-spot in Iceland means that interactions of tectonism and magmatism are generally driven by magmatism, such as dyke and fissure swarms (e.g., Dauteuil and Bergerat, 2005). The 1975-1984 intrusive Krafla rifting episode (Bjornsson et al., 1977 ) is another example of magmatic control, widening the fissure swarm along the length of the fractured zone by $0.3 \mathrm{~km}^{2}$ (Tryggvason, 1984). Magma intruded along pre-existing fractures to reach the surface (Opheim and Gudmundsson, 1989), possibly influenced by fractures with larger apertures compared to areas of high fracture density (Leckenby et al., 2005).

We document here the tectono-magmatic interaction at Monowai Volcanic Centre (MVC) in the Kermadec Arc (Figure 1A), a typical arc volcano that comprises a caldera 
complex, stratovolcano, extensive cone construction e.g., parasitic cones on the stratovolcano slopes, and extensional faulting (Davey, 1980; Wright et al., 2008; Chadwick et al., 2008; Graham et al., 2008). The MVC has been extensively surveyed using multibeam echosounder systems in 1986, 1998 and 2004 (Wright et al., 2008; Chadwick et al., 2008; Graham et al., 2008). The $30 \mathrm{kHz}$ multibeam echosounder system data acquired in 2004 (Figures 1B, 1C) provide the basis for this paper. A number of morphometric analysis tools are applied to multibeam bathymetry and backscatter data (Figures 1B, 1C) in order to decipher and quantify the interaction of tectonism and magmatism at MVC, in a regional context.

\section{TECTONIC SETTING}

The development of the active Tofua-Kermadec Arc (c. $1 \mathrm{Ma}$ ) and Lau-Havre Trough backarc since 5-6 Ma (Ruellan et al., 2003) is directly associated with the Pacific Australian subduction boundary along the Tonga-Kermadec Trench (Figure 1A). The Lau-Havre Trough separates the Tofua-Kermadec Arc from the remnant Lau-Colville arc, which became extinct 5-3.5 Ma (Gill, 1976; Wright et al 1990; Parson and Wright, 1996). The initiation of the Lau-Havre Trough is estimated at $5 \mathrm{Ma}$ (Gill, 1976), while for $35-37^{\circ} \mathrm{S}$ geophysical data published by Wright (1993) estimate an extension rate of 15-20 mm yr $\mathrm{mm}^{-1}$, and concur with the onset of rifting published by Gill (1976). The TofuaKermadec Arc has been active post-Pliocene, on or to the west of the Eocene-Miocene Tonga-Kermadec ridge (Wysoczanski et al., 2010). A major change in the arc-backarc system occurs at $\sim 25^{\circ} \mathrm{S}$ where the Louisville Seamount Chain is subducted into the Tonga-Kermadec Trench (Ruellan et al., 2003). Ruellan et al. (2003) proposed that the subduction of the Louisville seamount chain locked rifting in the Havre Trough at $\sim 26^{\circ} \mathrm{S}$. To the north, backarc opening has progressed to full seafloor spreading in the Lau Basin, whereas to the south, young semi-contiguous rifts with potentially short segments of spreading occur in the Havre Trough (Wysoczanski et al., 2010). The Pacific plate convergence rate increases northwards along the Kermadec Trench from $53 \mathrm{~mm} \mathrm{yr} r^{-1}$ at $34^{\circ} \mathrm{S}$, to $67 \mathrm{~mm} \mathrm{yr}^{-1}$ at $26^{\circ} 30^{\prime} \mathrm{S}$ (Bird, 2003; Figure 1A). Rifting in the Havre Trough between the Kermadec microplate and the Australian plate also increases northwards; it is estimated as $56 \pm 28 \mathrm{~mm} \mathrm{yr}^{-1}$ at $25^{\circ} \mathrm{S}$ (Bird, 2003), and 8-21 $\mathrm{mm} \mathrm{yr}^{-1}$ further south (Wallace et al., 2009). Delteil et al. (2002) interpreted the Havre 
Trough to be obliquely opening due to a progressive southward increase in oblique convergence of the Pacific Plate along the Kermadec Trench (Figure 1A). Furthermore, Graham et al. (2008) determined the least compressive stress direction from elongation directions of the majority of the calderas to be northwest-southeast, consistent with a $122^{\circ}$ rifting direction of magnitude $21 \pm 5 \mathrm{~mm} \mathrm{yr}^{-1}$ at $28^{\circ} \mathrm{S}$ (Pelletier and Louat, 1989). Accordingly the morphological expression of Kermadec Arc volcanism is influenced by the magnitude and direction of the local stress regime, which is dominantly transtensional (e.g., Delteil et al., 2002; Bonnardot et al., 2007).

MVC at $25^{\circ} 50^{\prime} \mathrm{S}$, at the northern limit of the Kermadec Arc (Figure $1 \mathrm{~A}$ ), is located to the east of a zone of semi-contiguous backarc grabens, which facilitate segmented rifting within the Havre Trough (Fujiwara et al., 2001). The MVC consists of a stratovolcano shoaling to $130 \mathrm{~m}$ water-depth (Graham et al., 2008), which is located to the south of a large nested caldera complex extending over $55 \mathrm{~km}^{2}$ and rising $\sim 1 \mathrm{~km}$ above the surrounding seafloor (Figure 1B, 1C). The northwest-southeast elongate caldera complex includes a $9 \mathrm{~km} \times 7 \mathrm{~km}$ outer caldera, which contains a $6 \mathrm{~km} \times 4 \mathrm{~km}$ inner, 1 $\mathrm{km}$ deep caldera (Graham et al., 2008). Numerous parasitic cones and fissure ridges are dispersed across the volcanic centre, concentrated between the northern slopes of the stratovolcano and the southern caldera rim. To the west and north, a series of well-developed NE-trending faults dissect the lower northern flanks of the MVC (Figure 1B, 1C) (Graham et al., 2008; Timm et al., 2011).

The Monowai stratovolcano is basaltic and has an estimated volume of $\sim 11 \mathrm{~km}^{3}$ (Graham et al., 2008). It is the locus of current magmatic activity, having formed a 'regrowth' cone of $0.023 \mathrm{~km}^{3}$ after a sector collapse event of $0.085 \mathrm{~km}^{3}$ within a 6 year period (1998-2007) (Wright et al., 2008; Chadwick et al., 2008). While the caldera complex hosts an active hydrothermal system with low temperature venting $\left(<60^{\circ} \mathrm{C}\right)$ (Leybourne et al., in revision), there is also hydrothermal activity at the stratovolcano. Seafloor samples collected in the inner caldera are andesitic, whereas the outer caldera is basaltic-andesitic. Samples from the calderas are in mutually exclusive ranges to the basaltic samples from Monowai stratovolcano (Graham et al., 2008). The caldera morphology indicates an explosive history, not usually associated with the 
relatively low silicic values from the calderas (Graham et al., 2008; Leybourne et al., in revision). Timm et al. (2011) suggest an influence at MVC of the subducted Louisville Seamount Chain (Figure 1A) and the Osbourn Trough an extinct Cretaceous spreading centre intersecting the Tonga Trench at $25^{\circ} 30^{\prime}$ S (Billen and Stock, 2000), the associated volatiles of which may in part explain the large size of the mafic calderas of Monowai. High volatile and glass contents within the andesites could have led to rapid magma chamber discharge and caldera collapse, which, supported by glass rich $\leq 41 \%$ basalts, indicates rapid quenching (Graham et al., 2008).

\section{DATA AND METHODOLOGY}

\subsection{Multibeam Data}

We use multibeam data (comprising bathymetry and backscatter) acquired by the R.V. Tangaroa in 2004 using a 30 kHz EM300 system (Wright et al., 2008). Navigational data were recorded via differential GPS with a positional accuracy of $\pm 5 \mathrm{~m}$. Hydromap $^{\mathrm{TM}}$ was used for backscatter data processing, making the standard corrections: attenuation of transmission loss, beam angle and range effects. Water column velocities were corrected using real-time in situ measurements, enabling the resultant multibeam data to be gridded at $25 \mathrm{~m}$ scale, with a vertical resolution of $\sim 1 \mathrm{~m}$.

\subsection{GIS Analysis}

Interpretation of the Monowai morphology is based on the multibeam data, and its subsequent analysis using Geographic Information System (GIS) software. ESRI® GIS software ArcGIS 9.3 were used to integrate and analyse the EM300 multibeam bathymetry and backscatter data. The GIS morphometric functions applied include Slope, Aspect, Hydrology tools, and Curvature functions (Figure 2). These algorithms use a $3 \times 3$ moving grid-cell to calculate results for the centre cell from the eight surrounding cells (ESRI, 2011). Seafloor Rugosity was determined using an ArcGIS add-in toolbar called the Benthic Terrain Modeler (Wright et al., 2005). These morphometric functions were applied to the multibeam bathymetry to aid analysis of tectono-magmatic structural features, and improve the accuracy and repeatability of volcano interpretation. The functions all highlight subtle changes in the bathymetry; whether directional (Aspect) or the extent of change of the seafloor (Slope), while the 
Hydrology tools and Curvature functions identify sharp changes in bathymetry (i.e., structure edges).

Each of the morphometric functions is explained below:

Slope calculates the maximum gradient in bathymetry of the centre cell from its eight neighbouring cells by using the directional first derivatives in the $\mathrm{x}$ (longitudinal) and $\mathrm{y}$ (latitudinal) directions (Figure 2A). Slope is calculated in degrees, with $0^{\circ}$ for horizontal and $90^{\circ}$ for vertical seafloor (Appendix, Equation 1).

Aspect classifies the seafloor into nine classes according to the direction that the maximum slope is facing (Figure 2B) (Appendix, Equation 2). The nine classes comprise the eight $45^{\circ}$ sector directions and 'flat' where Slope values are $0^{\circ}$ (ESRI, 2011).

Rugosity is the ratio of the three-dimensional surface area to the two-dimensional planar area (Figure 2C). Height changes from the centre cell to its eight neighbours are used to calculate the three-dimensional area, while the centre location of each cell is used to calculate the planar area.

Hydrology functions, Flow Direction and Flow Accumulation, are used to extract ridges within the seafloor data, as used in Micallef et al. (2007). The Hydrology tools are more typically based in subaerial settings and used in rainfall analysis. Flow Direction (an intermediary step to Flow Accumulation, creating the function input) determines the slope direction from the $3 \times 3$ grid centre cell to a neighbouring cell using an eightdirection flow model after Jenson and Domingue (1988), while also taking into account the distance between cells (ESRI, 2011). Flow Accumulation indicates where water channels would form, cells of zero Flow Accumulation (Figure 2D) in the submarine settings correspond to ridges.

The Curvature function (Figure 2E) is the second derivative of the bathymetry, or the maximum change in Slope of the centre cell to its eight neighbours, and generates both Profile Curvature (Figure 2F), and Plan Curvature (Figure 2G) maps. Profile Curvature is the Curvature of the seafloor in the direction of the slope (Appendix, Equation 3), whereas Plan Curvature is the Curvature perpendicular to the slope direction (Appendix, Equation 4; ESRI, 2011). The units of the functions of Curvature are degrees $\mathrm{m}^{-1}$ (Micallef et al., 2007). 
The results of these morphometric functions, the initial multibeam bathymetry and backscatter (Figure 1), and in some cases the (pseudo-3D) visualisation technique Hillshade (Figure 3) aid the interpretation of structural features. The more useful techniques to interpret the spatial distribution of ring faults, faults, volcanic vent cones, lava fields and fissure ridges, are detailed in Figure 3. The position of the structures are stored as GIS shapefiles with an accuracy of each linear segment of $\pm 25 \mathrm{~m}$, as the bathymetry is gridded at $25 \mathrm{~m}$ resolution (Wright et al., 2006a). Polygon shapefiles were used to delimit cones, lava fields, and fissure ridges, and polyline shapefiles were used for linear structures (i.e., the fissure ridge crests, faults and ring faults). Faults were interpreted at the footwall cut-off of the seafloor, and interpreted in linear segments. The fault scarp is defined by peaks of convex and concave bathymetry at the scarp limits (red and blue Profile Curvature respectively, Figure 3B), and is also seen in Slope (Figure $2 \mathrm{~A}$ ) and to a lesser extent in the other methods of analysis of Figure 2. A change in fault strike was taken to indicate a new fault segment for fault digitisation, when the fault segment was longer than $50 \mathrm{~m}$, and changed orientation more than $2^{\circ}$. The change in fault strike was interpreted from the footwall cut-off, with an accuracy of $\pm 5^{\circ}$. This method, producing segments with an average length of $240 \mathrm{~m}$, ensures sufficient sampling to identify linear structural orientations and their variation. As the bathymetry is gridded at 25 m resolution, the accuracy of the length of the interpreted structures is $\pm 25 \mathrm{~m}$. It is also applicable to fissure ridge crests, ring faults, and vent cone alignments, where several vent cones were interpreted as continuations of the same dyke feeder system. Structural elongation of the constructional magmatic structures defined the difference between interpreted vent cone alignments and fissure ridges, with more elongated structures classified as fissure ridges. Uncertainty in defining a feature as a fault or a fissure ridge was resolved using bathymetric transects (Figure 3F).

\subsection{Geomorphic and Tectonic Analyses}

Orientations of faults, fissure ridges, and cone structures were determined from the shapefiles, using 'fissure ridge crests' (Figure 3F) and 'vent cone alignments' (polyline shapefiles) for the polygonal structures. Fault segment strikes were length-weighted into $10^{\circ}$ class rose diagrams. The approximate orientation of the zone of semi-contiguous backarc grabens of the Havre Trough is $8^{\circ}$, as interpreted from 1 minute gridded satellite gravity anomalies. The orientation of the Kermadec Trench is interpreted as $10^{\circ}$ 
from the regional satellite derived bathymetry. The inner and outer caldera elongation directions were determined by the Standard Deviation Ellipse function of ArcGIS (ESRI, 2011), which fitted an ellipse to the topographic caldera rim. The ellipse fit to the caldera was weighted to the length of the interpreted caldera rim linear segments to ensure accuracy. The function also determined the ellipse centre point (Appendix, Equation 5), which was used with the elongation direction (Appendix, Equation 6) to determine caldera eccentricity, i.e. the short axis to long axis ratio. Such structural measurements provide comparable data between MVC and other volcanic centres along the Kermadec Arc. For example the relationships between orientations of the plate margin (the rifting Havre Trough), extensional faults, and the plate motion vector of the Kermadec microplate can be used to determine the type of extension at Monowai using the method of Tuckwell et al. (1996) - see Section 5.

Tectonic and magmatic interactions may be observed from morphometric analysis either through spatial overlap, or from structures that only form from the interaction of tectono-magmatic processes, such as dyke intrusion. Seafloor morphology may indicate where dykes reach near the surface, although most will be arrested at depth (Gudmundsson et al., 1999). During dyke injections, faults may be induced in front of the intrusion, which are later cut by the dyke, or faults may be induced above the dyke with the hanging wall intersecting the dyke (Rubin and Pollard, 1988). This process may be observed through a rise in the seafloor with a central dip (e.g., Rubin and Pollard, 1988) or graben structure if normal faults are induced (Pollard et al., 1983), which can be confirmed by a bathymetric transect, or through the relative indications of this structure from the Slope and Curvature analysis techniques. It is possible that this stage of dyke injection may not be observed, as a later eruptive event may mask the central dip within the bathymetric rise. If dyke injections are observed, the ratio of ridge heights could be used to determine the dip of the dyke (Pollard et al., 1983).

\subsection{Tectonic Deformation}

Measurement of fault throws was undertaken from high resolution bathymetric transects generated perpendicular to fault scarps at the respective lateral tips, and mid-point of each fault segment. A straight line was fitted to the fault scarp on the bathymetric transect (assuming a planar fault scarp), and extrapolated where necessary to determine throw values while minimising the effects of erosion and sedimentation. Throw values 
were projected onto two projection transect axes (Figure 4), parallel $\left(030^{\circ}\right)$ and perpendicular $\left(120^{\circ}\right)\left(\mathrm{Y}-\mathrm{Y}^{\prime}\right.$, Figure 4) to the rift trend. Cumulative throw profiles were calculated by re-sampling and summing fault throws every $100 \mathrm{~m}$ along-rift and every $50 \mathrm{~m}$ across-rift using the GMT software (Wessel, 2011). Cumulative throw profiles were projected on the two projection axes (Figure 4) to document tectonic deformation distribution across Monowai. Throws were measured on all faults interpreted; however, no throw value or facing direction was resolvable ( $\mathrm{D}$ in Figure 5A) for smaller faults at the limit of bathymetric and interpretive resolution (where throw values are less than 1 $\mathrm{m})$. As the vertical resolution of the bathymetry is $\sim 1 \mathrm{~m}$, this is also the uncertainty in the throw measurements. Throw values from caldera ring faults are not included in the transects as they relate to magma-chamber evacuation and accompany caldera collapse (Lipman, 1997), rather than resulting from the backarc extension alone.

\subsection{Volcanic Morphology}

As volcanism is the surficial expression of magmatism, as previously indicated, quantification of the volcanic structure volumes will also allow an indicative measure of magmatism. Surficial volcanism was quantified by calculating the volume of constructional “inflation” volcanism of cones and fissure ridges (also influenced by magmatism) and destructional volcanism of the caldera volumes. For each positive volcanic edifice, the bathymetry within the structure outline was extracted to find the maximum depth, which was assumed to be the planar base; the constructional volume was calculated between the planar base and the bathymetric surface. This process was reversed for the inner and outer calderas, to estimate the amount of material evacuated, with the volume calculated between the floor of the caldera and a planar limit assumed at the highest point along the caldera rim. Post-collapse constructional volumes from fissure ridges and vent cones were subtracted from the caldera volumes to determine the caldera collapse volumes, prior to caldera collapse there may have been additional volume from a previous dome structure, suggesting these caldera volumes to be minimum estimates. The volume of Monowai stratovolcano is a minimum due to a lack of survey coverage across the lower southeast flank of the edifice. These estimates of volcanic construct volumes assume planar bases only accounting for surficial volume, and not the full sub-surface magmatic intrusion volume which may be in the order of 180 times the extrusive volume (e.g., Ferguson et al., 2010). Nevertheless, using 
volcanic construct volumes as measures of volcanic activity provides a method of quantifying and comparing volcanism across MVC, and therefore an estimate of magmatism.

\section{RESULTS}

\subsection{Monowai Morphology}

MVC is dominated by the stratovolcano shoaling to $130 \mathrm{~m}$ water depth, the $1 \mathrm{~km}$ deep caldera complex, attendant smaller edifices, and an extensive fault population to the west (Figures 5,6). Higher seafloor backscatter values are interpreted as lava fields (e.g., Lipman et al., 1989; Wright and Gamble, 1999) around the inner and outer caldera rims (Figure 3D), and on the upper stratovolcano flanks (Figure 5A); while the Hillshade texture (Figure 3D) suggests the flow has a hummocky texture. Stratovolcano morphology is mostly uniform, with a gradually increasing gradient up to a maximum of $56^{\circ}$ (Figure $2 \mathrm{~A}$ ) across $3 \mathrm{~km}$ of the stratovolcano flanks towards the summit. A distinctive feature of the stratovolcano is the sector collapse scarp (Figure 5A) on the south-eastern flank (Chadwick et al., 2008; Wright et al., 2008), which is identified in Figure $2 \mathrm{G}$ in particular. Several parasitic cones and fissure ridges extend radially from Monowai stratovolcano on north to southeast facing slopes (Figure $5 \mathrm{~A}$ ), which due to their abrupt change in bathymetry are identified by most of the morphometric methods (Figure 2).

Ring faults delimit the boundaries of at least two nested calderas covering some 55 $\mathrm{km}^{2}$ (Figure 5A), from the higher Curvature values (Figure $2 \mathrm{E}$ ) around the caldera rims. The southern half of the caldera complex hosts numerous fissure ridges and parasitic cones up to $1 \mathrm{~km}$ in diameter, while the western outer caldera wall has been dissected by normal faults striking north-east (Figure 5A), aligned with the backarc rift. Although the elongation directions of the calderas are similar, there is a small but significant $10^{\circ}$ change from the outer caldera $\left(125^{\circ}\right)$ to the inner caldera $\left(135^{\circ}\right)$ (Figure 5E). Orientation of the former is consistent with the rifting direction of $122^{\circ}$ at $28^{\circ} \mathrm{S}$ determined from focal mechanisms (Pelletier and Louat, 1989), suggesting this direction to be the minimum principal (normal) stress direction. Caldera eccentricities of 0.764 for the inner caldera and 0.739 for the outer caldera, also suggest the normal 
stress $(\sigma)$ (a result of magmatic and tectonic processes at Monowai) minimum to maximum ratio is similar for both calderas during magma chamber collapse. The Kermadec trench axis interpreted from gravity measurements ( $170 \mathrm{~km}$ to the east, Figure $7 \mathrm{~A}$ ) strikes $010^{\circ}$ (Figure 5E). The orientation of Monowai is not perpendicular to the Kermadec Trench (Figure 5E), and hence caldera elongation is not solely controlled by large-scale subduction processes.

Minor volcanism also occurs to the northwest of the stratovolcano, with a $2 \mathrm{~km}$ cone structure within the rift system, cross cut by the faults (Figure 5A). Cones and fissure ridges around the southern edges of the calderas may be syn-collapse structures, or may result from post-collapse magma pressure exceeding the normal stress on the ring fault (Delaney et al., 1986), exploiting the fracture as a conduit. The smallest cones occur within the morphological caldera rim, whilst cones with diameters greater than 1 $\mathrm{km}$ occur within $4 \mathrm{~km}$ south of the caldera centre, with the exception of a $1 \mathrm{~km}$ diameter dome in the centre of the inner caldera (Figure 5A). Further volcanic constructional structures extend north-northwest $\left(355^{\circ}\right)$ from the caldera complex, although the structures within this population strike to the northeast, similar to the average orientations of magmatic structures of $041^{\circ}$ (fissure ridges, Figure 5C) and $039^{\circ}$ (vent alignments, Figure 5D). Also to the north of the caldera complex are possible small dyke intrusions, although they only exhibit morphological depressions of $<5 \mathrm{~m}$, and therefore are indistinguishable from surficial undulations at this scale.

Volcanism has been quantified by using measurements of constructional volume, which may also indicate the extent of intrusive dyking, where it reaches the seafloor. Total volumes are as follows: fissure ridges $1.4 \mathrm{~km}^{3}$; cones $2.1 \mathrm{~km}^{3}$; and the stratovolcano $18 \mathrm{~km}^{3}$ (similar to the $11 \mathrm{~km}^{3}$ calculated by Graham et al., 2008) (Figure $6 \mathrm{~A})$. The volcanic constructional volumes of fissure ridges, cones and the stratovolcano indicate a greater magmatic volume at depth. The negative evacuated caldera volumes are calculated as $30.9 \mathrm{~km}^{3}$ for the outer caldera and $13.6 \mathrm{~km}^{3}$ for the inner caldera, not including post collapse constructional volcanism. Although the cone and fissure ridge volumes are much less than caldera and stratovolcano volumes; the relative proportions of cone formation and fissure ridges indicate magmatic intrusives surrounding the 
caldera are dominantly accommodated by cone formation, with implications for likely emplacement mechanisms at depth. The caldera and stratovolcano are host to numerous small $\left(<0.04 \mathrm{~km}^{3}\right)$ parasitic cones, clustered concentrically within the southern half of the caldera complex, extending radially from the northwest-southeast stratovolcano flank (Figure 6A). Between the stratovolcano and caldera complex there is a slight dominance of small cones in the west and fissure ridges to the east, although there are also parasitic cones to the east (Figure 5A). Larger cones of $0.16-0.41 \mathrm{~km}^{3}$ are spaced on average $4 \mathrm{~km}$ apart around the south-eastern half of the caldera complex (Figure 6A).

\subsection{Fault Structures}

The Monowai fault population predominantly occurs to the west and the north of the caldera complex (Figure 5A), with an average strike (excluding caldera ring faults) of $031^{\circ}$ (Figure $5 \mathrm{~B}$ ). Faults vary in length from a few hundred metres to $9 \mathrm{~km}$, and are symmetrically disposed about a central axis (Figure 5A). For example north-western faults within the population face southeast and south-eastern faults face northwest, although the former are more common across MVC (Figure 5A). In both the $3 \mathrm{~km}$ wide zone of faults to the west of the caldera complex, and the approximately $8 \mathrm{~km}$ wide region of faulting to the north, shorter length faults are concentrated in the centre of the fault population (Figure 5A). However, in the western region, faulting is denser and apparently contained within bounding faults, with limited linkage between the shorter faults, compared to the widely dispersed faulting to the north of the caldera complex (Figure 5A). The bathymetric profile of the western faulted region confirms bounding faults and steep, and recently formed faults. We interpret the fault population to the west of Monowai caldera complex to be a nascent rift graben. The most westerly fault within the surveyed area (position X in Figure 5A) is especially arcuate, displacing 700 $\mathrm{m}$ perpendicular to its strike. Propagation of the fault to the northeast is visible at the seafloor where it splays into three faults at position $X$ (Figure 5A). The spatial distribution of the major fault at position $X$ (Figure 5A) and separate faults to the northeast suggests that a relay ramp is starting to form. Fault throw data does not confirm the presence of a relay ramp (Figure 6A), suggesting that linkage is yet to 
develop significantly enough to be detected through summing throw measurements after the method of Peacock and Sanderson (1991).

Tectonic deformation at Monowai has been determined by the measurement of discrete fault throws (Figure 6). Deformation intensity is greatest in the west of MVC, nearest the regional Havre Trough backarc rifting, with up to $141 \mathrm{~m}$ of throw at a single location (Figure 6A). Further, the bounding faults of the western nascent rift graben also have higher fault throw values than the surrounding fault population (Figure 6A). To the northeast of the graben, throw values are less than $30 \mathrm{~m}$, until the edge of the survey area where three faults have maximum throws up to $136 \mathrm{~m}$ (Figure 6A). The two zones of faulting west and north of the caldera complex (Figure 5A), are particularly clear within the southwest to northeast rift parallel transect ( $X-X^{\prime}$ Figure $6 \mathrm{~A}$, Figure 6B), which correspond to throw peaks at $10 \mathrm{~km}(260 \mathrm{~m})$ and $27 \mathrm{~km}(325 \mathrm{~m})$ along the transect. Between the two peaks in throw at $10 \mathrm{~km}$ and $27 \mathrm{~km}$ (Figure 6B) there appears to be a throw deficit, which is concentrated at approximately $20 \mathrm{~km}$ where throw reaches $0 \mathrm{~m}$. The location of negligible throw coincides with seafloor constructs of cones and fissure ridges. These magmatic constructs strike northeast and are concentrated within a zone extending north-northwest $\left(355^{\circ}\right)$ from the caldera (Figure 5A).

The across rift throw transect $\left(Y-Y^{\prime}\right.$ Figure $6 \mathrm{~A}$, Figure $\left.6 \mathrm{C}\right)$ is more variable than the along rift throw transect $\left(X-X^{\prime}\right.$ Figure $6 \mathrm{~A}$, Figure $\left.6 \mathrm{~B}\right)$. There are three peaks in total throw at $1.5 \mathrm{~km}, 2.2 \mathrm{~km}$ and $2.7 \mathrm{~km}$ along the across rift transect, though the maximum total throw is only $122 \mathrm{~m}$. Greater throw values within the northwest (Figure $6 \mathrm{C}$ ) are consistent with the proximity to the backarc in the west, and the migration of tectonic deformation eastward, as proposed in arc evolution models (e.g. Wright et al., 1996; Fujiwara et al., 2001). The irregularity of the throw profile of the across rift transect highlights the complexity of tectonic deformation at a kilometre scale, which is also recorded by the spatial distribution of seafloor rifting (Figure 6A). Displacement-length fault profiles created from this fault throw methodology provide insight into fault properties; however, they are not the focus of this present study. 
On a regional scale analysis using orientations of the length-weighted average fault strike $\left(031^{\circ}\right.$, Figure $\left.5 A\right)$, Havre Trough axis determined from satellite gravity (Figures $5 E, 7 A)$, and the Bird (2003) plate motion vector (Figure 7A), allowed the use of the Tuckwell et al. (1996) method (Figure 7B, 7C), detailed in Section 5. This methodology found the dominant rifting mechanism of the Havre Trough at Monowai to be transtensional (Figure 7D), rather than oblique opening or orthogonal spreading.

\section{DISCUSSION}

\subsection{Tectono-Magmatic Evolution Of Monowai}

Detailed spatial analysis of magmatic features and the distribution and style of faulting provide a robust basis to document the evolution of Monowai volcanic centre. Prior to the magmatic intrusion of the Kermadec Arc, rifting along a north-northeast 008을 axis (Figure 7A) initiated the Havre Trough backarc, as suggested by the relative timing of the Havre Trough initiation at $\sim 5 \mathrm{Ma}$ (Gill, 1976; Wright, 1993) and the TofuaKermadec Arc active post-Pliocene (Wysoczanski et al., 2010). The initiation of rifting may have been coeval with magmatism along the Kermadec Arc, or may even postdate the arc magmatism; however we prefer the model of Wright et al. (1996) indicating a trenchward migration of rifting and arc magmatism, which concurs with the estimated ages above. Early faulting may have provided a tectonically preconditioned "crust" through which arc magmatism has migrated trenchward (e.g., Wright et al., 1996; Delteil et al., 2002). The migration of deformation eastward is supported by greater throw values to the west of the fault population at Monowai (Figure 6A), although the across-rift pattern of throw variation is fairly irregular (Figure $6 C$ ). In addition the spatial distribution of faults at position $X$ (Figure $5 A$ ) suggests the development of a relay ramp, though throw values do not confirm the relay ramp, this would indicate the migration of deformation is ongoing. Therefore the crustal fabric direction before magmatic intrusion may be similar to the average fault orientation of $031^{\circ}$ (Figure $5 \mathrm{~B}$ ), possibly with a diffuse distribution similar to faults north of the caldera complex (Figure 5A).

Faults at Monowai vary in length from $9 \mathrm{~km}$ to a few hundred metres, with longer faults bounding the nascent rift graben west of the caldera complex. To the west of the 
caldera complex faults, there is a high density of shorter faults in the centre of the graben, which are more diffuse to the north of the caldera. If the rate of lateral fault growth is assumed to be constant (Walsh and Watterson, 1988), this would suggest the concentration of shorter faults are the locus of current rifting and younger than most of the northern faults.

After the initial rifting, one of the earlier identifiable magmatic structures is the outer caldera, though pre-caldera constructional magmatism cannot be determined from the existing data. The outer caldera is interpreted to be older than the inner caldera as the morphological rim has greater gravitational collapse; also the caldera walls are eroded and overprinted by faults and magmatic features to a greater degree (Figure 5A). There is some gravitational collapse with possible local structural imprint on northern outer caldera ring faults, although this is not present on the southern ring faults, possibly due to the presence of magmatic constructs. The stratovolcano is interpreted to be younger than the outer caldera as it is not dissected by faults, although it is not possible to determine the relative timing of the inner caldera and the stratovolcano from the geomorphology alone.

Smaller scale structures of Monowai can also be used to determine their relative timing. For example some of the caldera adjacent faults to the west of the complex (Figure 5A) may have been present before the outer caldera collapse, while to the southwest a $2 \mathrm{~km}$ diameter cone is dissected, suggesting a complex interplay of tectonism and magmatism. However, most faults west of the caldera complex formed at a similar time to the inner caldera and stratovolcano, probably caused by loading on the lithosphere from the weight of the $18 \mathrm{~km}^{3}$ stratovolcano (e.g., the arcuate fault at position $\mathrm{X}$, Figure $5 \mathrm{~A}$ ) or formed during caldera collapse. Greater timing resolution is possible using the population of magmatic structures extending north-northwest $\left(355^{\circ}\right)$ from the caldera centre (Figure 5A). These latter structures may have formed after or with the $031^{\circ}$ fault fabric, as the cones and fissure ridges individually strike northeast, despite the population trending $355^{\circ}$. These structures coincide with the position of the along-rift throw deficit (of $\sim 220 \mathrm{~m}$ across a $10 \mathrm{~km}$ profile, Figure $6 \mathrm{~B}$ ) concentrated at $20 \mathrm{~km}$ along rift within Figure 6B. The strain missing in the throw 
profile may be accommodated magmatically through a dyke trending $355^{\circ}$, or through magma propagating to the surface via several sub-vertical fractures. If so these magmatic constructs may reflect a greater magma pressure than the crustal (compressional) stress at depth, allowing the magmatic exploitation of pre-existing fault fabric (Delaney et al., 1986), acting as planes of weakness for Andersonian dykes (Anderson, 1951). If the magmatic constructs are coeval with rifting, they may indicate dyke intrusion which propagated to the surface, although the $355^{\circ}$ trend of the population could suggest a common magmatic source as observed elsewhere by Lara et al. (2006).

High fault throws (1-141 m) may indicate that rifting is dominantly accommodated through faulting, instead of through dyke intrusion (Opheim and Gudmundsson, 1989). There may be several smaller dykes across the surveyed area, with some possible examples particularly observed to the north of Monowai; however, these potential intrusions only have associated decreases in bathymetry of $<5 \mathrm{~m}$. This suggests where magmatic intrusion does occur, the intrusion is likely to reach the surface as cones or fissure ridges compared to dyke injection with morphological expression, either due to tectonic force or surface heat flow (Watanabe et al., 1999).

\subsection{Kinematic Framework}

The $010^{\circ}$ trend of the Kermadec Trench segment nearest Monowai, or the $008^{\circ}$ Havre Trough segment (Figure 7A), has no direct tectono-geomorphic imprint on the volcanic complex. Nor does the convergence direction of the Pacific plate (Figure 1A), as structures oriented approximately $010^{\circ}$ or $100^{\circ}$ would be observed. A $10^{\circ}$ change in caldera elongation from the inner to the outer calderas (Figure 5E, Table 1) is similar to the $\sim 10^{\circ}$ change from tectonically controlled features (faults orientated $031^{\circ}$, Table 1 ) to magmatically controlled features (fissure ridges, striking $041^{\circ}$ and vent lines orientated $039^{\circ}$, Table 1$)$.

The inner caldera elongation direction $\left(135^{\circ}\right.$, Table 1 , Figure $\left.5 \mathrm{E}\right)$ is approximately perpendicular to magmatic features, and likewise for the outer caldera $\left(125^{\circ}\right.$, Table 1 , Figure $5 \mathrm{E}$ ) and tectonic structures. Assuming all the faults analysed are normal (due to 
their high angle and backarc tectonic setting), the principal stress orientations can indicate changes in the regional stress directions during the evolution of Monowai. The principal stress directions are defined as: maximum in the vertical plane, intermediate (maximum horizontal compressional stress) $\mathrm{S}_{\mathrm{H} \max }$ parallel to the strike of the structure, and minimum (minimum horizontal compressional stress) $S_{h \min }$ perpendicular to $S_{H \max }$. If the regional stresses are anisotropic, caldera elongation is likely to occur in the direction of $S_{h \min }$ (Bosworth et al., 2003; Holohan et al., 2005) as this direction requires the least force to overcome the bulk cohesion in the brittle plate above the magma chamber. However, the caldera will only form when the magmatic pressure associated with the magma chamber, is greater than the minimum horizontal stress $\left(S_{h m i n}\right)$. The principal stress directions can also be indicated on a local scale by the propagation direction of dykes or "magma-feeding fractures" (Anderson, 1951; Corazzato and Tibaldi, 2006), as indicated by the vent lines and fissure ridge orientations of $39^{\circ}$ and $41^{\circ}$, respectively (Figure 5), which propagate parallel to $S_{H \max }$ (Nakamura, 1977), as applied by e.g., Johnson and Harrison (1990) and Corazzato and Tibaldi (2006). Monowai stratovolcano differs from the regional trend of $\mathrm{S}_{\mathrm{Hmax}}$, suggesting a local control on $\mathrm{S}_{\mathrm{Hmax}}$, with vent cones and fissure ridges on the stratovolcano north-eastern slope, indicating radial dykes extending from the stratovolcano centre.

The same $\sim 10^{\circ}$ change in orientations of the outer caldera and faults, to the inner caldera and magmatic structures is considered here significant. Although it is important to note the outer caldera has deformed since its formation. The tectonic structures are oriented approximately perpendicular to the outer caldera (Table 1), in the direction of $S_{H \max }$ possibly when the outer caldera was formed, if rifting of the Havre Trough preceded arc volcanism (Wright, 1993; Wysoczanski et al., 2010). In contrast, the magmatic structures are oriented approximately perpendicular to the inner caldera (Table 1). The magmatic structures are interpreted to have formed largely post-caldera collapse, which may have weakened the crust, suggesting a subtle shift in the horizontal principal stress direction. This suggests that the $S_{\mathrm{hmin}}$ at the time of the inner caldera formation may have been influenced by greater magmatic pressures over tectonic stresses, due to the formation of magmatic structures along the strike of $\mathrm{S}_{\mathrm{Hmax}}$; compared to the outer caldera formation, when magmatic 
pressures would have been lower as faults are dominantly formed in the direction of $\mathrm{S}_{\mathrm{Hmax}}$. The inner caldera emplacement may also have been influenced by pre-existing conduits from the magma chamber collapse associated with the outer caldera, which would have provided planes of weakness and therefore less bulk cohesion of the lithosphere to overcome for the inner caldera. This hypothesis assumes that the Andersonian theory of principal stresses can be applied to magmatic structures (Nakamura, 1977), which at mid-upper crustal depths are tectonically controlled as fractures or fault planes that are magmatically exploited (e.g., Delaney et al., 1986). However, it is important to note that magmatic populations may be affected by structures around the caldera complex affecting average orientations, creating a high degree of variability in the corresponding $\mathrm{S}_{\mathrm{H} \max }$ and $\mathrm{S}_{\mathrm{hmin}}$ (Table 1). Further, due to the extent of post-formation deformation of the outer caldera, the current elongation may not be the original orientation, hence it may be difficult to determine if there is a subtle $\left(10^{\circ}\right)$ shift in principal stress directions.

Volumes of the volcanic structures suggest a predominance of vent cone formation $\left(2.1 \mathrm{~km}^{3}\right)$ compared to fissure ridges $\left(1.4 \mathrm{~km}^{3}\right)$, however, this does not take into account material intruded at depth, which may be up to two orders of magnitude greater than the extrusive volume of material (e.g., Ferguson et al., 2010). Although the two calderas differ in volume (the outer caldera $30.9 \mathrm{~km}^{3}$, and the inner caldera $13.6 \mathrm{~km}^{3}$ ), the stress ratios are likely to be similar during caldera formation, as the eccentricities are similar with 0.739 for the outer caldera and 0.764 for the inner caldera. The outer caldera has been subject to greater deformation and topographical gravitational collapse post-formation (Figure $5 \mathrm{~A}$ ), suggested by its irregular outline compared to the more oval shaped inner caldera (Figure 5E), although this should not affect the eccentricity results greatly as they are based on the axes, not the regularity of the caldera rim.

The extensional style at Monowai can be analysed in terms of transtension, oblique opening or orthogonal spreading, based on the model of Sanderson and Marchini (1984) and analysis of Tuckwell et al. (1996) (Figure 7B-D), where $\alpha$ is the angular difference between the plate margin and the plate motion vector, and $\Phi$ the angular difference 
between the plate motion vector and the extensional faults (Figure 7B). The position of the values of Monowai on the $\alpha-\Phi$ plot indicates that the transtensional model is most applicable (Figure 7D). Rifting within the Havre Trough nearest Monowai has been determined as transtensional from the morphometric analysis, where rifting occurs across a zone of semi-contiguous rift grabens within the Havre Trough, which make the classification of the tectonic setting more complex than a single definitive rift axis. With the progression of arc volcanism trenchward, the current edifice of Monowai stratovolcano may evolve, displaying structures more indicative of transtension (Mathieu et al., 2011).

The transtensional regime of Monowai (Figure 7D) may be affected by the regional setting detailed in Figure 7A, although to test this a comparison of the rest of the Kermadec Arc volcanoes would be required. The analysis technique of Tuckwell et al. (1996) using $\alpha$ and $\Phi$ (Figure 7B-D) to quantify the degree of the type of rifting, allows simple comparison of the type of rifting between extensional sites worldwide, including backarc rifts and full oceanic spreading centres. Finding Monowai to be a transtensional regime agrees with the findings of Delteil et al. (2002) and Bonnardot et al. (2007) who also interpreted the Kermadec - Havre Trough to be transtensional through other methods.

\section{CONCLUSIONS}

Monowai volcanic centre comprises a nested caldera complex over $55 \mathrm{~km}^{2}$ in area with an attendant young $18 \mathrm{~km}^{3}$ stratovolcano on its southwest caldera rim. The outer caldera (with an evacuated volume of $30.9 \mathrm{~km}^{3}$ ) has an elongate direction of $125^{\circ}$ and an inner caldera (evacuated volume $13.6 \mathrm{~km}^{3}$ ) is elongated along $135^{\circ}$. The caldera elongation directions indicate the minimum principal stress direction $\left(S_{h m i n}\right)$. Similar eccentricities ( 0.74 for the outer caldera and 0.76 for the inner caldera) suggest similar mechanisms of formation. To the west of the caldera complex and overprinting the outer caldera, is a nascent rift graben, part of the regional tectonic system migrating trenchward at Monowai, which has an average fault strike of $031^{\circ}$. Elongate vent cones (striking $039^{\circ}$ ) are greater in volume at $2.1 \mathrm{~km}^{3}$ than the fissure ridges (striking $041^{\circ}$ ) with volume of $1.4 \mathrm{~km}^{3}$, suggesting a predominance of cone formation with 
implications for magmatic plumbing systems. High throw values up to $141 \mathrm{~m}$ suggest the area is tectonically controlled, apart from locally by the large scale arc volcanism of the caldera complex and stratovolcano. The north-northwest $\left(355^{\circ}\right)$ trending population of fissure ridges and vent cones which individually strike northeast, the direction of maximum horizontal principal stress $\left(\mathrm{S}_{\mathrm{Hmax}}\right)$, is interpreted to accommodate strain magmatically, coinciding with a throw deficit.

Pre-existing faults are interpreted to control the orientation of later magmatic intrusions, and the large magmatic structure of the stratovolcano induces fault formation due to gravitational loading. We interpret a temporal shift in the tectonomagmatic interaction, reflected in caldera elongation directions. When the inner caldera was formed, $S_{h m i n}$ was influenced by greater magmatic pressures than tectonic stresses, compared to relatively lower magmatic pressures when the outer caldera formed. Pre-existing conduits from the formation of the outer caldera will have also reduced the lithostatic strength for formation of the inner caldera. Both of these factors may have led to the change in the inner and outer caldera orientations of approximately $10^{\circ}$.

Morphometric analysis resolving the relationship of $\alpha$ and $\Phi$ using the method of Tuckwell et al. (1996), has quantitatively determined the type of rifting within the Havre Trough and around Monowai to be transtensional. As the rifting within the Havre Trough is distributed across a zone of semi-contiguous grabens and not a single rift axis, morphological expression alone could not define the type of rifting.

The morphometric method applied to Monowai is also applicable to other submarine (or indeed planetary) volcanic centres where structural analysis is restricted to surface morphology. Analysis methods used at Monowai have shown geomorphic analysis to be effective in understanding the structure and evolution of a submarine volcanic centre. A combination of morphometric analysis techniques and multibeam bathymetry and backscatter data is used in the interpretation of magmatic and tectonic structures, with Plan Curvature and Profile Curvature techniques particularly useful in improving the accuracy and speed of interpretation. 


\section{Acknowledgements}

This project is funded by the University of Southampton and National Oceanography Centre, United Kingdom. The data were acquired during the 2004 R.V. Tangaroa NZAPLUME III voyage, and John Mitchell and Richard Garlick are thanked for the at-sea acquisition and data processing. Julie Rowland and an anonymous reviewer are thanked for their constructive comments which substantially improved the final manuscript, and we are thankful to Lionel Wilson (Editor) for his continued support to see the submitted manuscript published.

\section{REFERENCES}

Anderson, E. M., 1951, The dynamics of faulting and dyke formation with applications to Britain, $2^{\text {nd }}$ Ed., Oliver and Boyd, Edinburgh, pp. 1-191

Bellotti, F., Capra, L., Groppelli, G., Norini, G., 2006, Tectonic evolution of the centraleastern sector of Trans Mexican Volcanic Belt and its influence on the eruptive history of the Nevado de Toluca volcano (Mexico). J. Volcanol. Geotherm. Res., 158 (1-2), 2136, doi:10.1016/j.jvolgeores.2006.04.023

Billen, M. I., Stock, J., 2000, Morphology and origin of the Osbourn Trough, J. Geophys. Res., 105 (B6), 13481-13489, doi:10.1029/2000JB900035

Bird, P., 2003, An updated digital model of plate boundaries, Geochem. Geophys. Geosyst., 4 (3), 1027, doi:10.1029/2001GC000252

Björnsson, A. Saemundsson, K., Einarsson, P., Tryggvason, E., Grönvold, K., 1977, Current rifting episode in north Iceland. Nat., 266, 318-323, doi:10.1038/266318a0

Bonnardot, M.-A, Régnier, M., Ruellan, E., Christova, C., Tric, E., 2007, Seismicity and state of stress within the overriding plate of the Tonga-Kermadec subduction zone, Tectonics, 26, TC5017, doi:10.1029/2006TC002044. 
Bosworth, W., Burke, K., Strecker, M., 2003, Effect of stress fields on magma chamber stability and the formation of collapse calderas, Tectonics, 22 (4), 1042, doi:10.1029/2002TC001369

Brown, C. J., Blondel, P., 2009, Developments in the application of multibeam sonar backscatter for seafloor habitat mapping, Appl. Acoust. 70 (10), 1242-1247, doi:10.1016/j.apacoust.2008.09.006

Bull, J. M., Minshull, T. A., Mitchell, N. C., Dix, J. K., Hardardottir, J., 2005, Magmatic and tectonic history of Iceland's western rift zone at Lake Thingvallavatn, Geol. Soc. Am. Bull., 117 (11/12), 1451-1465, doi:10.1130/B25729.1

Burrough, P. A., McDonnell, R. A., 1998, Principles of Geographical Information Systems, Oxford University Press, Oxford, pp. 190-193

Calais, E., D'oreye, N., Albaric, J., Deschamps, A., Delvaux, D., Déverchère, J., Ebinger, C., Ferdinand, R. W., Kervyn, F., Macheyeki, A. S., Oyen, A., Perrot, J., Saria, E., Smets, B., Stamps, D. S., Wauthier, C., 2008, Strain accommodation by slow slip and dyking in a youthful continental rift, East Africa. Nat., 456, 783-787, doi:10.1038/nature07478

Campbell, M. E., Rowland, J. V., Wright, I. C., Smith, I. E. M., 2007, Oblique rifting along the central and southern Kermadec Arc front $\left(30^{\circ}-36^{\circ} \mathrm{S}\right)$, SW Pacific, Geochem. Geophys. Geosyst., 8 (1), Q01007, doi:10.1029/2006GC001504

Cembrano, J., Lara, L., 2009, The link between volcanism and tectonics in the southern volcanic zone of the Chilean Andes: A review, Tectonophys., 471 (1-2), 96-113, doi:10.1016/j.tecto.2009.02.038

Chadwick, W. W. Jr., Wright, I. C., Schwarz-Schampera, U., Hyvemaud, O., Reymond, D., de Ronde, C. E. J., 2008, Cyclic eruptions and sector collapses at Monowai submarine volcano, Kermadec arc: 1998-2007, Geochem. Geophys. Geosyst., 9 (10), Q10014, doi:10.1029/2008GC002113 
Corazzato, C., Tibaldi, A., 2006, Fracture control on type, morphology and distribution of parasitic volcanic cones: An example from Mt. Etna, Italy, J. Volcanol. Geotherm. Res., 158 (1-2), 177-194, doi:10.1016/j.jvolgeores.2006.04.018

Corti, G., Bonini, M., Conticelli, S., Innocenti, F., Manetti, P., Sokoutis, D., 2003, Analogue modelling of continental extension: a review focused on the relations between the patterns of deformation and the presence of magma, Earth-Sci. Rev., 63 (3-4), 169-247, doi: 10.1016/S0012-8252(03)00035-7

Davey, F., 1980, The Monowai Seamount: An active submarine volcanic centre on the Tonga-Kermadec ridge, N. Z. J. Geol. Geophys., 23 (4), 533-536, doi:10.1080/00288306.1980.10424124

Dauteuil, O. \& Bergerat, F., 2005, Interactions between magmatism and tectonics in Iceland: a review. Geodin. Acta, 18, 1-9

Delaney, P. T., Pollard, D. D., Ziony, J. I., McKnee, E. H., 1986, Field Relations Between Dikes and Joints: Emplacement Processes and Paleostress Analysis, J. Geophys. Res., 91 (B5), 4920-4938, doi:10.1029/JB091iB05p04920

Delteil, J., Ruellan, E., Wright, I., Matsumoto, T., 2002, Structure and structural development of the Havre Trough (SW Pacific), J. Geophys. Res., 107 (B7), 2143-2159, doi:10.1029/2001JB000494

ESRI, 2011, ArcGIS Desktop 9.3 Help, [online] Available at: <http://webhelp.esri.com/arcgisdesktop/9.3/> [Accessed 19 December 2011]

Favalli, M., Karatson, D., Mazzarini, F., Pareschi, M. T., Boschi, E., 2009, Morphometry of scoria cones located on a volcano flank: A case study from Mt. Etna (Italy), based on high-resolution LiDAR data, J. Volcanol. Geotherm. Res., 186 (3-4), 320-330, doi:10.1016/j.jvolgeores.2009.07.011 
Ferguson, D. J., Barnie, T. D., Pyle, D. M., Oppenheimer, C., Yirgu, G., Lewi, E., Kidane, T., Carn, S., Hamling, I., 2010, Recent rift-related volcanism in Afar, Ethiopia, Earth Planet. Sci. Lett., 292, 409-418, doi:10.1016/j.espl.2010.02.010

Francis, P., Oppenheimer, C., 2004, Volcanoes, $2^{\text {nd }}$ Ed. Oxford University Press, Oxford, pp. $349-350$

Fujiwara, T., Yamazaki, T., Joshima, M., 2001, Bathymetry and magnetic anomalies in the Havre Trough and southern Lau Basin: from rifting to spreading in back-arc basins, Earth Planet. Sci. Lett., 185 (3-4), 253-264, doi:10.1016/S0012-821X(00)00378-2

Gill, J. B., 1976, Composition and age of Lau Basin and Ridge volcanic rocks: Implications for evolution of an interarc basin and remnant arc, Geol. Soc. Am. Bull., 87, 1384-1395, doi: 10.1130/0016-7606(1976)87<1384:CAAOLB>2.0.CO;2

Graham, I. J., Reyes, A. G., Wright, I. C., Peckett, K. M., Smith, I. E. M., Arculus, R. J., 2008, Structure and petrology of newly discovered volcanic centers in the northern Kermadec-southern Tofua arc, South Pacific Ocean, J. Geophys. Res., 113, B08S02, doi:10.1029/2007JB005453

Gudmundsson, A., Marinoni, L. B., Marti, J., 1999, Injection and arrest of dykes: implication for volcanic hazards, J. Volcanol. Geotherm. Res., 88 (1-2), 1-13, doi: 10.1016/S0377-0273(98)00107-3

Hauber, E., Grott, M., Kronberg, P., 2010, Martian rifts: Structural geology and geophysics, Earth Planet. Sci. Lett., 294 (3-4), 393-410, doi:10.1016/j.epsl.2009.11.005

Holohan, E. P., Troll, V. R., Walter, T., R., Münn, S., McDonnell, S., Shipton, Z. K., 2005, Elliptical calderas in active tectonic settings: an experimental approach, J. Volcanol. Geotherm. Res., 144 (1-4), 119-136, doi:10.1016/j.jvolgeores.2004.11.020 
Huvenne, V. A. I., Mcphail, S. D., Wynn, R. B., Furlong, M., Stevenson, P., 2009, Mapping Giant Scours in the Deep Ocean, Eos Trans. Am. Geophys. Union, 90 (32), 274-275, doi:10.1029/2009EO320002

Jenson, S. K., Domingue, J. O., 1988, Extracting Topographic Structure from Digital Elevation Data for Geographic Information System Analysis, Photogramm. Eng. Remote Sens., 54 (11), 1593-1600, doi:0099-1112/88/5411-1593\$02.25/0

Johnson, C. A. \& Harrison, C. G. A., 1990, Neotectonics in central Mexico, Phys. Earth Planet. Inter., 64 (2-4), 187-210, doi:10.1016/0031-9201(90)90037-X

Keir, D., Pagli, C., Bastow, I. D., Ayele, A., 2011, The magma-assisted removal of Arabia in Afar: Evidence from dike injection in the Ethiopian rift captured using InSAR and seismicity, Tectonics, 30, TC2008, doi:10.1029/2010TC002785

Lamarche, G., Lurton, X., Verdier, A.-L., Augustin, J.-M., 2011, Quantitative characterisation of seafloor substrate and bedforms using advanced processing of multibeam backscatter-Application to Cook Strait, New Zealand, Cont. Shelf Res., 31 (2), S93-S109, doi:10.1016/j.csr.2010.06.001

Lara, L. E., Lavenu, A., Cembrano, J. \& Rodríguez, C., 2006, Structural controls of volcanism in transversal chains: Resheared faults and neotectonics in the Cordón Caulle-Puyehue area $\left(40.5^{\circ} \mathrm{S}\right)$, Southern Andes, J. Volcanol. Geotherm. Res., 158 (1-2), 70-86, doi:10.1016/j.jvolgeores.2006.04.017

Leat, P. T., Tate, A. J., Tappin, D. R., Day, S. J., Owen, M. J., 2010, Growth and mass wasting of volcanic centers in the northern South Sandwich arc, South Atlantic, revealed by new multibeam mapping, Mar. Geol., 275 (1-4), 110-126, doi:10.1016/j.margeo.2010.05.001 
Leckenby, R. J., Sanderson, D. J., Lonergan, L., 2005, Estimating flow heterogeneity in natural fracture systems, J. Volcanol. Geotherm. Res., 148 (1-2), 116-129, doi:10.1016/j.jvolgeores.2005.03.017

Leybourne, M. I., Schwarz-Schampera, U., de Ronde, C. E. J., Baker, E. T., Faure, K., Walker, S. L., Butterfield, D. A., Resing, J., Hannington, M. D., Massoth, G. J., Clark, M., Timm, C., Graham, I. J., Wright, I. C., In Revision, Submarine magmatic-hydrothermal systems at the Monowai Volcanic Centre, Kermadec arc, Econ. Geol.

Lipman, P. W., Clague, D. A., Moore, J. G., Holcomb, R. T., 1989, South Arch volcanic field - Newly identified young lava flows on the sea floor south of the Hawaiian Ridge, Geol., 17 (7), 611-614, doi:10.1130/0091-7613(1989)017<0611:SAVFNI>2.3.CO;2

Lipman, P. W., 1997, Subsidence of ash-flow calderas: relation to caldera size and magma-chamber geometry, Bull. Volcanol., 59 (3), 198-218, doi:10.1007/s004450050186

Mathieu, L., Van Wyk De Vries, B., Pilato, M., Troll, V. R., 2011, The interaction between volcanoes and strike-slip, trantensional and transpressional fault zones: Analogue models and natural examples. J. Struct. Geol., 33 (5), 898-906, doi:10.1016/j.jsg.2011.03.003

Micallef, A., Berndt, C., Masson, D. G., Stow, D. A. V., 2007, A technique for the morphological characterization of submarine landscapes as exemplified by debris flows of the Storegga Slide, J. Geophys. Res., 112, F02001, doi:10.1029/2006JF000505

Mitchell, N. C., Lofi, J., 2008, Submarine and subaerial erosion of volcanic landscapes: comparing Pacific Ocean seamounts with Valencia Seamount, exposed during the Messinian Salinity Crisis, Basin Res., 20 (4), 489-502, doi:10.1111/j.13652117.2008.00355.x 
Nakamura, K., 1977, Volcanoes as possible indicators of tectonic stress orientation -principle and proposal, J. Volcanol. Geotherm. Res., 2 (1), 1-16, doi:10.1016/03770273(77)90012-9

Opheim, J. A., Gudmundsson, A., 1989, Formation and geometry of fractures, and related volcanism, of the Krafla fissure swarm, northeast Iceland, Geol. Soc. Am. Bull., 101 (12), 1608-1622, doi:10.1130/0016-7606(1989)101<1608:FAGOFA>2.3.CO;2

Parson, L. M., Wright, I. C., 1996, The Lau-Havre-Taupo back-arc basin: A southwardpropagating, multi-stage evolution from rifting to spreading, Tectonophys., 263 (1-4), 1-22, doi:10.1016/S0040-1951(96)00029-7

Peacock, D. C. P., Sanderson, D. J., 1991, Displacements, segment linkage and relay ramps in normal fault zones, J. Struct. Geol., 13 (6), 721-733, doi:10.1016/01918141(91)90033-F

Pelletier, B., Louat, R., 1989, Seismotectonics and present-day relative plate motions in the Tonga-Lau and Kermadec-Havre region, Tectonophys., 165 (1-4), 237-250, doi:10.1016/0040-1951(89)90049-8

Pollard, D. D., Delaney, P. T., Duffield, W. A., Endo, E. T., Okamura, A. T., 1983, Surface deformation in volcanic rift zones, Tectonophys., 94 (1-4), 541-584, doi: 10.1016/00401951(83)90034-3

Pyle, D. M., Elliott, J. R., 2006, Quantitative morphology, recent evolution, and future activity of the Kameni Islands volcano, Santorini, Greece. Geosph., 2 (5), 253-268, doi:10.1130/GES00028.1

Rowland, J. V., Wilson, C. J. N., Gravely, D. M., 2010, Spatial and temporal variations in magma-assisted rifting, Taupo Volcanic Zone, New Zealand, J. Volcanol. Geotherm. Res., 190 (1-2), 89-108, doi:10.1016/j.jvolgeores.2009.05.004 
Rowland, S. K., Mackay, M. E., Garbeil, H., Mouginis-Mark, P. J., 1999, Topographic analyses of Kilauea Volcano, Hawai'i, from interferometric airborne radar, Bull. Volcanol., 61 (1-2), 1-14, doi: 10.1007/s004450050258

Rubin, A. M. \& Pollard, D. D., 1988, Dike-induced faulting in rift zones of Iceland and Afar, Geol., 16 (5), 413-417, doi:10.1130/0091-7613(1988)016<0413:DIFIRZ>2.3.CO;2

Ruellan, E., Delteil, J., Wright, I.C., Matsumoto, T., 2003, From rifting to active spreading in the Lau Basin - Havre Trough backarc system (SW Pacific): Locking/unlocking induced by seamount chain subduction, Geochem. Geophys. Geosyst., 4 (5), 8909, doi:10.1029/2001GC000261

Sanderson, D.J., Marchini, W.R.D., 1984, Transpression, J. Struct. Geol., 6 (5), 449-458, doi:10.1016/0191-8141(84)90058-0

Sonnette, L., Angelier, J., Villemin, T., Bergerat, F., 2010, Faulting and fissuring in active oceanic rift: Surface expression, distribution and tectonic-volcanic interaction in the Thingvellir Fissure Swarm, Iceland. J. Struct. Geol., 32 (4), 407-422, doi:10.1016/j.jsg.2010.01.003

Spinks, K. D., Acocella, V., Cole, J. W., Bassett, K. N., 2005, Structural control of volcanism and caldera development in the transtensional Taupo Volcanic Zone, New Zealand, J. Volcanol. Geotherm. Res., 144 (1-4), 7-22, doi:10.1016/j.jvolgeores.2004.11.014

Taylor, B., 1992, Rifting and the volcanic-tectonic evolution of the Izu-Bonin-Mariana Arc, In Taylor, B. \& Fujioka, K. (Eds.) Proceedings of the Ocean Drilling Program, Scientific Results, 126, College Station, TX, Ocean Drilling Program, pp. 627-651

Timm, C., Graham, I. J., de Ronde, C. E. J., Leybourne, M. I., Woodhead, J., 2011, Geochemical evolution of Monowai volcanic center: New insights into the northern 
Kermadec arc subduction system, SW Pacific, Geochem. Geophys. Geosyst., 12 (8), Q0AF01, doi:10.1029/2011GC003654

Tryggvason, E., 1984, Widening of the Krafla fissure swarm during the 1975-1981 volcano-tectonic episode, Bull. Volcanol., 47 (1), 47-69, doi:10.1007/BF01960540

Tuckwell, G. W., Bull, J. M., Sanderson, D. J., 1996, Models of fracture orientation at oblique spreading centres, J. Geol. Soc., 153, 185-189, doi:10.1144/gsjgs.153.2.0185

van Wyk de Vries, B., Merle, O., 1996, The effect of volcanic constructs on rift fault patterns, Geol., $24 \quad$ (7), 643-646, doi:10.1130/00917613(1996)024<0643:TEOVCO>2.3.CO;2

Villamor, P., Berryman, K. R., Nairn, I. A., Wilson, K., Litchfield, N., Ries, W., 2011, Associations between volcanic eruptions from Okataina volcanic centre and surface rupture of nearby active faults, Taupo Rift, New Zealand: Insights into the nature of volcano-tectonic interactions, Geol. Soc. Am. Bull., 123 (7-8), 1383-1405, doi:10.1130/B30184.1

Wallace, L. M., Ellis, S., Mann, P., 2009, Collisional model for rapid fore-arc block rotations, arc curvature, and episodic back-arc rifting in subduction settings, Geochem. Geophys. Geosyst., 10 (5), Q05001, doi:10.1029/2008GC002220

Walsh, J. J., Watterson, J., 1988, Analysis of the relationship between displacements and dimensions of faults, J. Struct. Geol., 10 (3), 239-247, doi:10.1016/01918141(88)90057-0

Watanabe, T., Koyaguchi, T., Seno, T., 1999, Tectonic stress controls on ascent and emplacement of magmas. J. Volcanol. Geotherm. Res., 91 (1), 65-78, doi:10.1016/S0377-0273(99)00054-2 
Wessel, P., 2011, The Generic Mapping Tools, [online] Available at: http://gmt.soest.hawaii.edu/ [Accessed 23 June 2011]

Wright, D. J., Lundblad, E. R., Larkin, E. M., Rinehart, R. W., Murphy, J., Cary-Kothera, L., Draganov, K., 2005, ArcGIS Benthic Terrain Modeler, Corvallis, Oregon, Oregon State University, Davey Jones Locker Seafloor Mapping/Marine GIS Laboratory and NOAA Coastal Services Center. Available at: http://dusk.geo.orst.edu/djl/samoa/tools.html [Accessed June 2010]

Wright, I. C., 1993, Pre-spread rifting and heterogeneous volcanism in the southern Havre Trough back-arc basin, Mar. Geol., 113, 179-200, doi:10.1016/00253227(93)90017-P

Wright, I. C., Gamble, J. A., 1999, Southern Kermadec submarine caldera arc volcanoes (SW Pacific): caldera formation by effusive and pyroclastic eruption, Mar. Geol., 161, 207-227, doi:10.1016/S0025-3227(99)00040-7

Wright, I., Carter, L., Lewis, K., 1990, GLORIA Survey of the Oceanic-Continental Transition of the Havre-Taupo Back-Arc Basin, Geo-Mar. Lett., 10 (2), 59-67, doi:10.1007/BF02431023

Wright, I. C., Parson, L. M., Gamble, J. A., 1996, Evolution and interaction of migrating cross-arc volcanism and backarc rifting: An example from the southern Havre Trough (3520'-37º), J. Geophys. Res., 101 (B10), 22071-22086, doi:10.1029/96JB01761

Wright, I. C., Worthington, T. J., Gamble, J. A., 2006a, New multibeam mapping and geochemistry of the $30^{\circ}-35^{\circ} \mathrm{S}$ sector, and overview, of southern Kermadec arc volcanism, J. Volcanol. Geotherm. Res., 149 (3-4), 263-296, doi:10.1016/j.jvolgeores.2005.03.021

Wright, I. C., Chadwick, W. W. Jr., de Ronde, C. E. J., Reymond, D., Hyvernaud, O., Gennerich, H. -H., Stoffers, P., Mackay, K., Dunkin, M. A., Bannister, S. C., 2008, 
Collapse and reconstruction of Monowai submarine volcano, Kermadec arc, 19982004, J. Geophys. Res., 113, B08S03, doi:10.10299/2007JB005138

Wright, T. J., Ebinger, C., Biggs, J., Ayele, A., Yirgu, G., Keir, D., Stork, A., 2006b, Magmamaintained rift segmentation at continental rupture in the 2005 Afar dyking episode. Nature, 442, 291-294.

Wysoczanski, R. J., Todd, E., Wright, I. C., Leybourne, M. I., Hergt, J. M., Adam, C., Mackay, K., 2010, Backarc rifting, constructional volcanism and nascaent disorganised spreading in the southern Havre Trough backarc rifts (SW Pacific), J. Volcanol. Geotherm. Res., 190, 39-57, doi:10.1016/j.jvolgeores.2009.04.004 


\section{Figure Captions}

Fig. 1 (A) Tofua-Kermadec Arc regional tectonic setting, modified from Campbell et al. (2007), locating Monowai volcanic centre (MVC) within the red box at the northern Kermadec Arc. Pacific plate convergence rates (in blue) are in $\mathrm{mm} \mathrm{yr}^{-1}$ (Bird, 2003). Position of the backarc grabens is based on the bathymetric lows of the zone of semicontiguous backarc grabens within the Havre Trough. (B) MVC Bathymetry (in metres below sea level), with contours at $100 \mathrm{~m}$ intervals and outlines of the inner and outer caldera limits. (C) MVC Backscatter, higher values indicate a greater intensity of energy reflected, with outlines of the inner and outer caldera limits.

Fig. 2 Comparison of various quantitative analysis methods applied to MVC, where (A) - Slope, (B) - Aspect, (C) - Rugosity, (D) - Zero Flow Accumulation, (E) - Curvature, (F) Profile Curvature, and (G) - Plan Curvature.

Fig. 3 The most useful datasets to interpret particular tectonic and magmatic structures at a submarine volcanic centre, for ring faults (A), faults (B), cones (C), lava fields $(D)$, fissure ridges $(E)$ and fissure ridge crests $(F)$. Where analysis techniques are labelled as; Hillshade (1), Backscatter (2), Slope (3), Curvature (4), Profile Curvature (5) and Plan Curvature (6).

Fig. 4 The projection of measured throw values onto along and across ( $Y$ - $\left.Y^{\prime}\right)$ rift transects. The rift transects are located in Figure 6.

Fig. 5 (A) Structural interpretation of Monowai Volcanic Centre, overlain upon a Hillshade image. Position $X$ indicates the early stage of a possible relay ramp of the arcuate western fault. (B) Length-weighted rose diagram of the fault population distribution and average trend. (C) Length-weighted rose diagram of the fissure ridge population distribution and average trend. (D) Length-weighted rose diagram of the average vent line population distribution and average trend. (E) Orientations of the 
trench axis segment nearest Monowai, and the inner and outer caldera elongation directions relative to the caldera outlines.

Fig. 6 (A) Spatial distribution of throw (m) intensity and magmatic volumes $\left(\mathrm{km}^{3}\right)$, where the transects of $6 \mathrm{~B}, 6 \mathrm{C}$ are located. Throw value class breaks are defined by 'Natural Breaks (Jenks)' that are determined within ArcGIS. (B) Along rift throw transect, marked by $X-X^{\prime}$ in Figure 6A. (C) Across rift throw transect, marked by $Y^{\prime} Y^{\prime}$ in Figure 6A.

Fig. 7 Regional Context of Monowai

(A) Position of Monowai relative to the Havre Trough and Kermadec Trench, and the relative orientations of the regional structures and the plate motion vectors of Bird (2003). The Havre Trough orientation is determined from satellite gravity measurements, while the Kermadec Trench orientation is interpreted from the bathymetric low. (B) Definitions of $\alpha$ and $\Phi$ as defined by Tuckwell et al. (1996) using the orientations of the rifting plate margin, extensional fractures and the plate motion vector of Bird (2003). (C) Models of Tuckwell et al. (1996) detailing plate margin geometries depending on varying relationships between $\alpha$ and $\Phi$, whether transtension, oblique opening or orthogonal spreading, with associated plan view diagrams of the tectonic setting. (D) A plot of $\alpha$ against $\Phi$ to define the plate margin geometry type at Monowai, after Tuckwell et al. (1996), where the spreading ridge values of $\alpha$ and $\Phi$ determined by Tuckwell et al. (1996) are included within the plot.

Table 1

Orientations of structures from primary observations, maximum horizontal stress $\left(S_{H \max }\right)$ and minimum horizontal stress $\left(S_{h \min }\right)$. Where horizontal stress values of structures are 'Observed', they are the same as orientations of the structures, otherwise, the values are calculated by the perpendicular angle to the observed horizontal stress value. 


\section{APPENDIX}

Equation 1 - (Burrough and McDonnell, 1998; Micallef et al., 2007; ESRI, 2011)

Slope $=\tan ^{-1}\left(\sqrt{(d z / d x)^{2}+(d z / d y)^{2}}\right)$

Where $\mathrm{x}$ is the longitudinal direction, $\mathrm{y}$ is the latitudinal direction and $\mathrm{z}$ the vertical direction.

Equation 2 - ESRI, (2011)

Aspect $=180 / \pi \operatorname{atan} 2\left(d z / d y^{*}-d z / d x\right)$

Equation 3 As expressed by Micallef et al. (2007)

Profile Curvature

$=\frac{-\left((d z / d x)^{2} d^{2} z / d x^{2}+2\left(d z / d x d z / d y d^{2} z / d x d y\right)+(d z / d y)^{2} d^{2} z / d y^{2}\right)}{\left((d z / d x)^{2}+(d z / d y)^{2}\right) \sqrt{\left(1+(d z / d x)^{2}+(d z / d y)^{2}\right)^{3}}}$

Equation 4 As expressed by Micallef et al. (2007)

\section{Plan Curvature}

$$
=\frac{-\left((d z / d y)^{2} d^{2} z / d x^{2}-2\left(d z / d x d z / d y d^{2} z / d x d y\right)+(d z / d x)^{2} d^{2} z / d y^{2}\right)}{\sqrt{\left((d z / d x)^{2}+(d z / d y)^{2}\right)^{3}}}
$$

Equation 5 - ESRI, (2011)

Centre $X=\sqrt{1 / n \sum_{i=1}^{n}\left(x_{i}-\bar{X}\right)^{2}}$

Centre $Y=\sqrt{1 / n \sum_{i=1}^{n}\left(y_{i}-\bar{Y}\right)^{2}}$

Equation 6 - ESRI, (2011)

$\theta=\tan ^{-1}\left(\frac{\sum_{i=\mathbf{1}}^{n} x_{i}{ }^{2}-\sum_{i=\mathbf{1}}^{n} y_{i}{ }^{2}+\sqrt{\left(\sum_{i=\mathbf{1}}^{n} x_{i}{ }^{2}-\sum_{i=\mathbf{1}}^{n} y_{i}^{2}\right)^{2}+4\left(\sum_{i=1}^{n} x_{i} y_{i}\right)^{2}}}{2 \sum_{i=1}^{n} x_{i} y_{i}}\right)$

The centre point of the standard deviation ellipse is calculated by the function's algorithm (equation 5). Where $\mathrm{n}$ is the total number of features, $x_{\mathrm{i}}$ and $y_{\mathrm{i}}$ the coordinates for the ith straight line segment within the caldera outline, and $\bar{X}, \bar{Y}$ is the mean centre of the features used to calculate the ellipse through the Spatial Statistics toolbox. 
The elongation axis orientation of the standard deviation ellipse is determined by equation 6 , where $\bar{x}_{i}$ and $\bar{y}_{i}$ are the deviations of the $\mathrm{x}, \mathrm{y}$ co-ordinates of each feature from the mean centre $(\bar{X}, \bar{Y})$. 

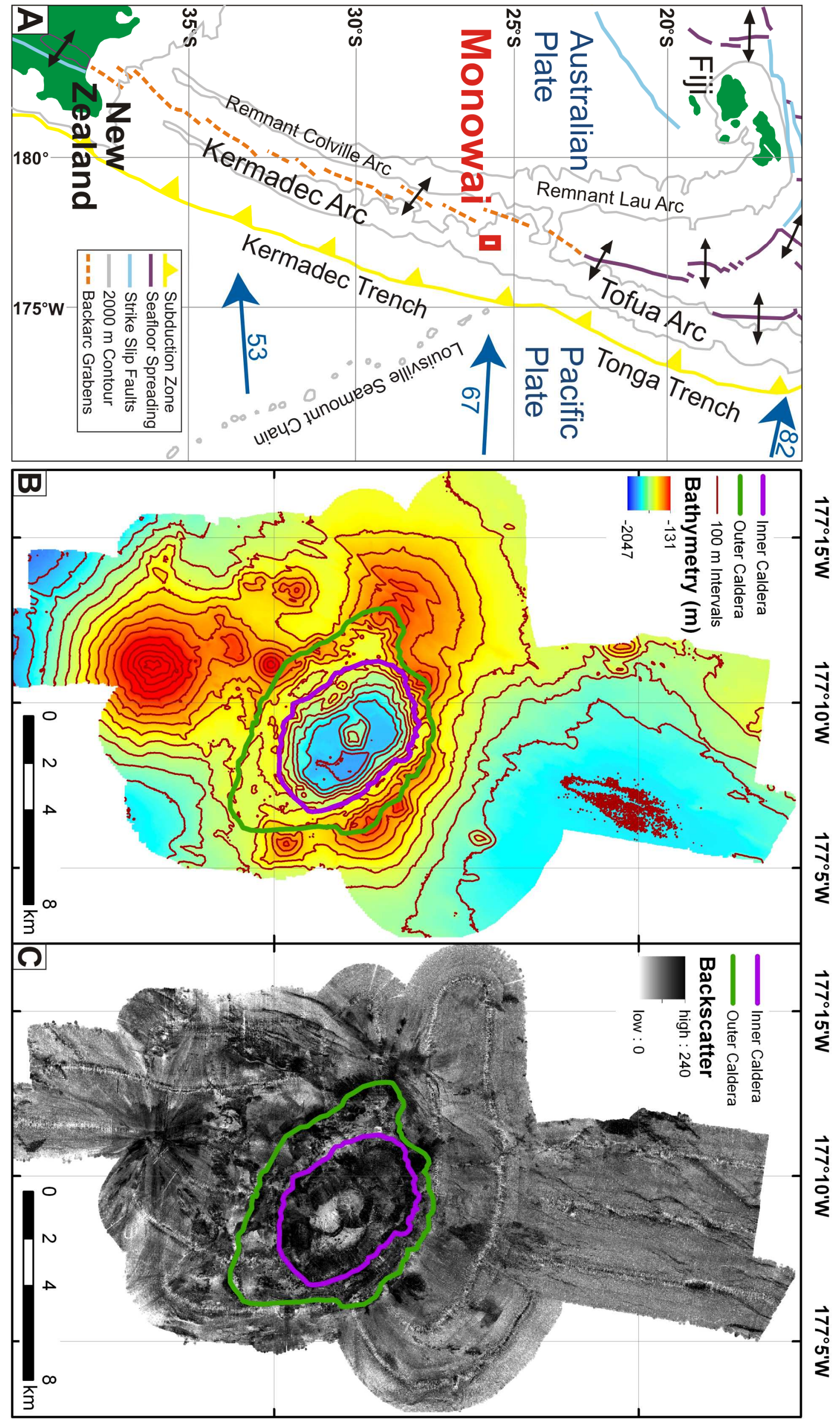




$25^{\circ} 55^{\prime} \mathrm{S} \quad 25^{\circ} 50^{\prime} \mathrm{S} \quad 25^{\circ} 45^{\prime} \mathrm{S}$

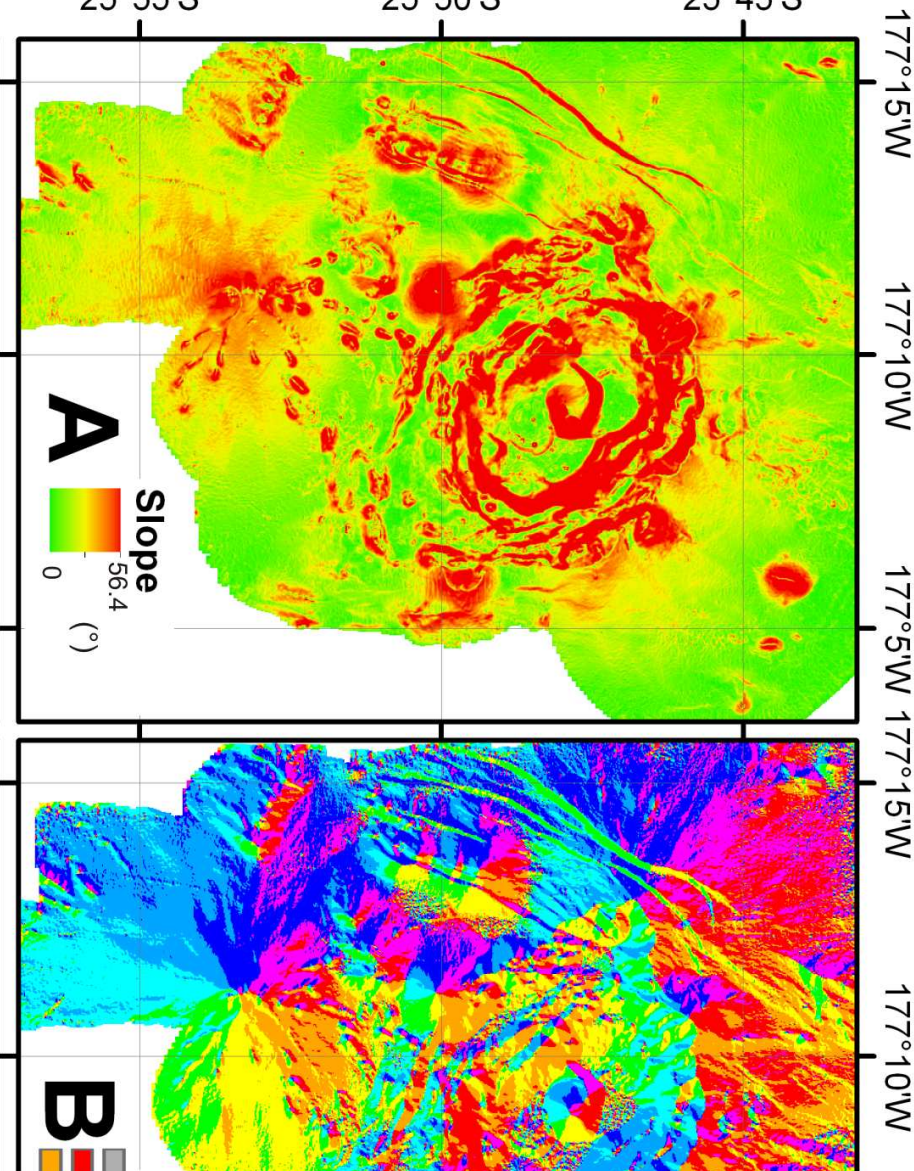

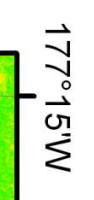
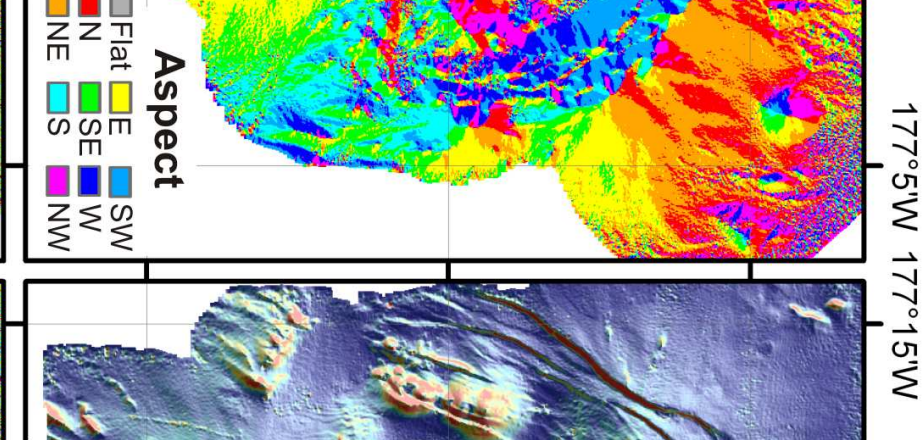

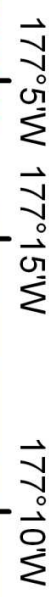

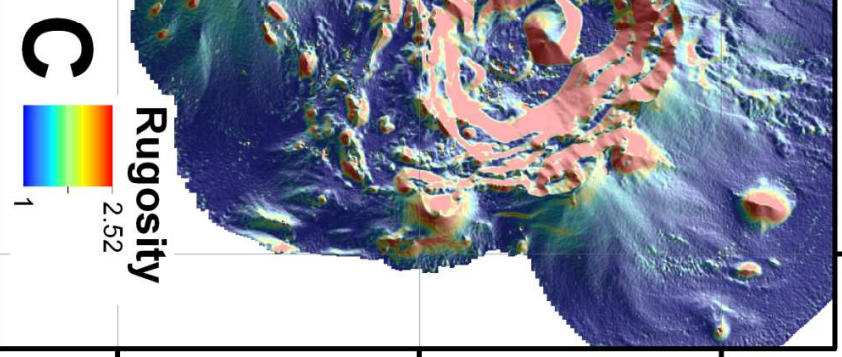

$\vec{\nabla}$ i

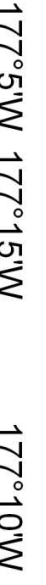

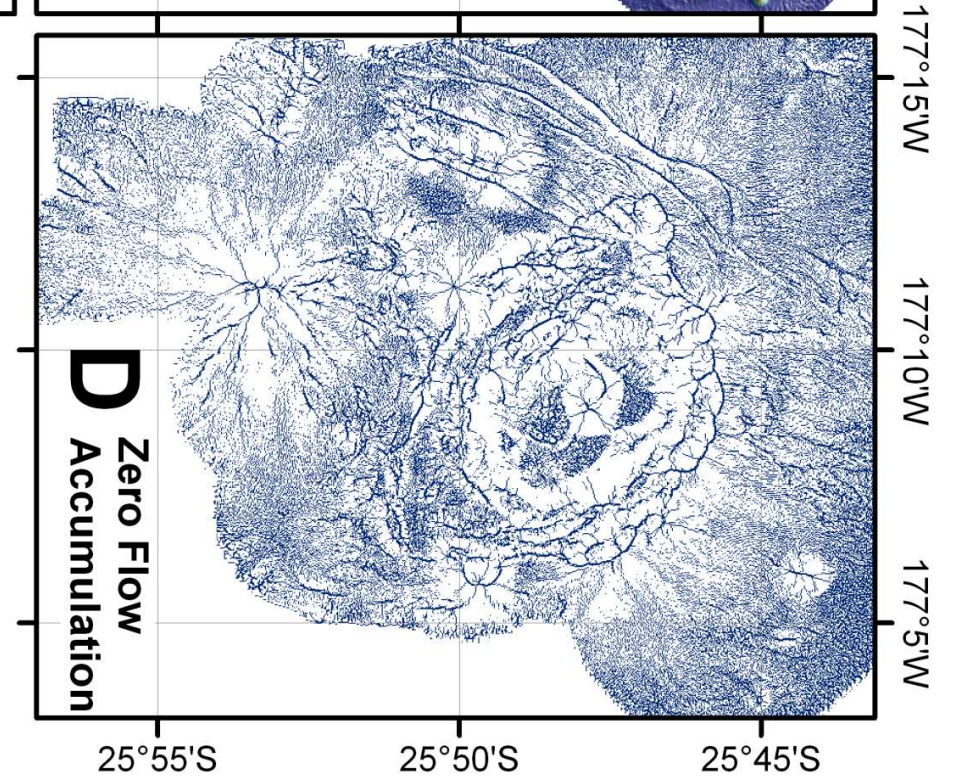




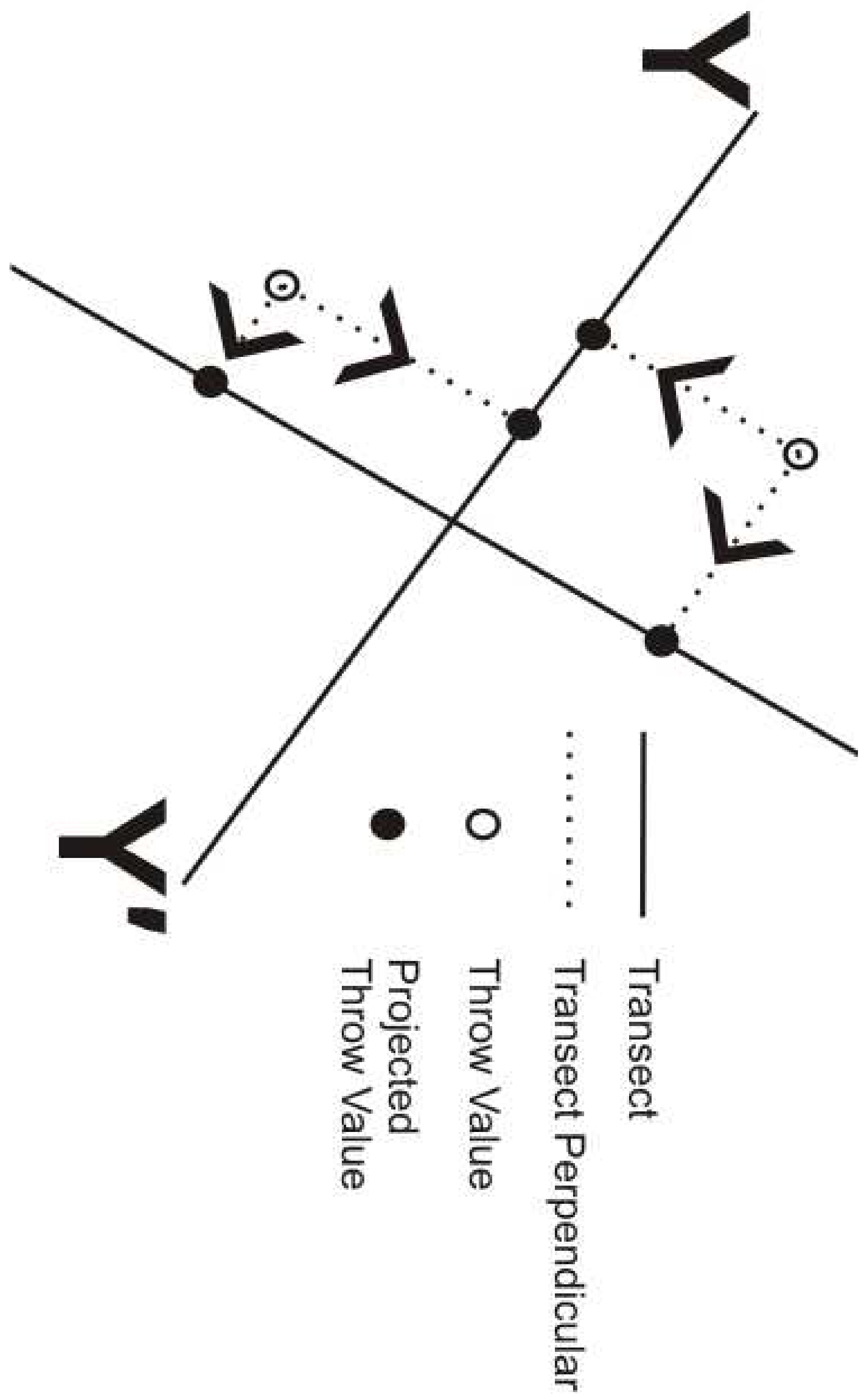


A

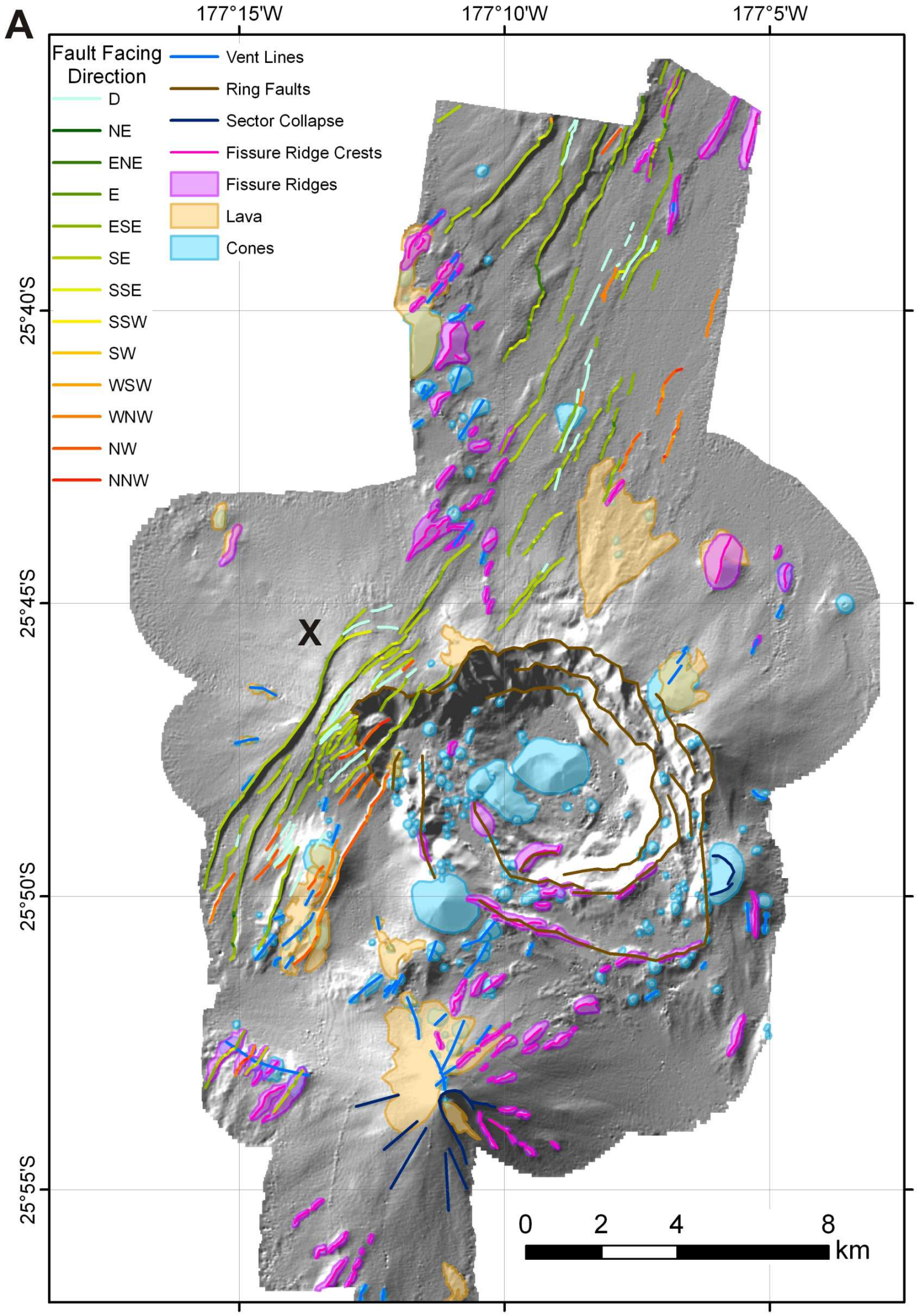

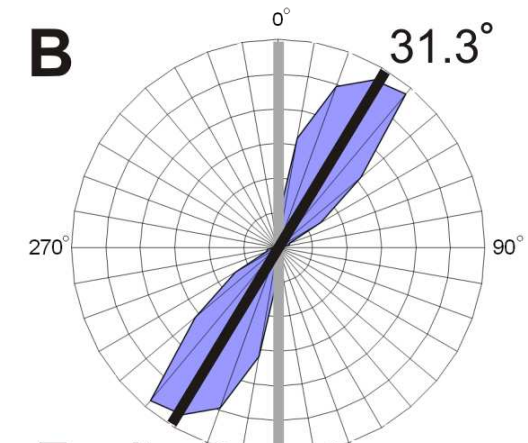

Faults
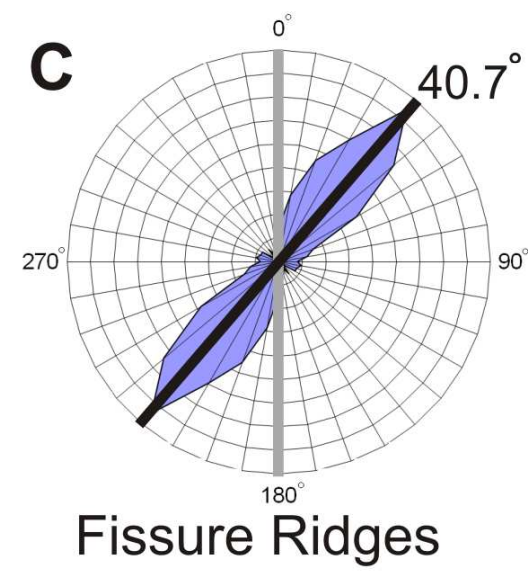

D

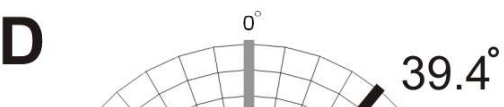

270

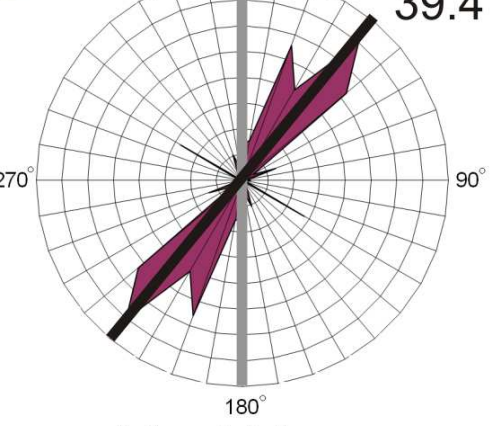

\section{Vent Lines}

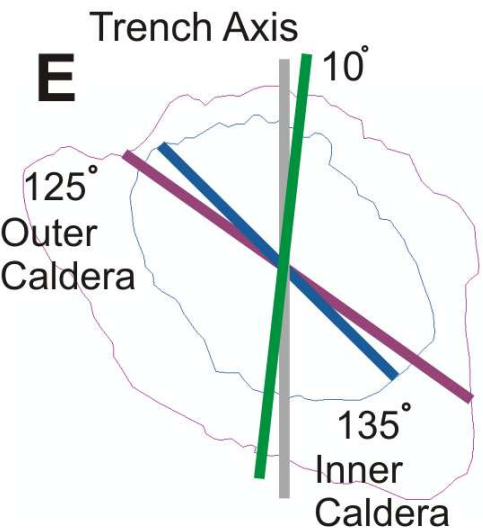


